\title{
Fine-scale biophysical interactions drive prey availability at a migratory stopover site for Phalaropus spp. in the Bay of Fundy, Canada
}

\author{
L. H. Thorne ${ }^{1,2, *}$, A. J. Read ${ }^{2}$ \\ ${ }^{1}$ School of Marine and Atmospheric Sciences, Stony Brook University, Stony Brook, New York 11794, USA \\ ${ }^{2}$ Division of Marine Science and Conservation, Duke University, 135 Duke Marine Lab Road, Beaufort, \\ North Carolina 28516, USA
}

\begin{abstract}
We examined the role of biophysical interactions in structuring the foraging habitat of phalaropes Phalaropus spp. at an important migratory stopover site in the Bay of Fundy. We sampled both biological and physical aspects of the environment and integrated these observations into generalized additive models (GAMs). Strong tidal currents interact with steep bathymetric gradients at the Brier Island ledges to enhance vertical mixing, creating dense surface aggregations of Calanus finmarchicus copepods at fine temporal and spatial scales. The resulting spatial variation in copepod density in near-surface waters creates a highly heterogeneous foraging environment for phalaropes, which are obligate surface feeders. Models of phalarope abundance over the ledges suggested that phalaropes forage on upwelled zooplankton aggregations as they drifted downstream. Our results highlight the importance of considering underlying physical processes when assessing hotspots of prey aggregations for marine species, particularly within highly dynamic systems such as the Bay of Fundy. This is particularly relevant to considerations of the conservation status of red-necked phalaropes Phalaropus lobatus, which have abandoned a long-time migratory stopover area previously used by more than one million birds during the mid-1980s.
\end{abstract}

KEY WORDS: Upwelling · Zooplankton · Calanus finmarchicus · Bay of Fundy · Tidal currents · Phalarope

\section{INTRODUCTION}

Biophysical interactions structure habitat patches in marine environments at a variety of spatial and temporal scales (Haury et al. 1978). The importance of fine-scale heterogeneity in marine systems is exemplified by the importance of oceanographic features that create prey patches and aggregate or attract animals from lower to upper trophic levels, thus creating important 'hotspots' of marine life (e.g. Alldredge \& Hamner 1980, Hamner \& Hauri 1981, Franks 1992, Rodhouse et al. 1996, Griffin 1999,
Johnston et al. 2005). In particular, predators that are restricted to feeding at the water's surface, such as many seabird species, often rely on oceanographic features to make prey accessible through upwelling or other mechanisms (e.g. Haney 1986, 1987, Brown \& Gaskin 1988, Pakhomov \& McQuaid 1996, van Franeker et al. 2002). It is important to understand how such oceanographic processes create foraging opportunities for marine predators and thus structure these hotspots in space and time.

Phalaropes Phalaropus spp. offer an interesting opportunity to examine the effects of sub-surface 
biophysical processes in structuring foraging habitat at the water's surface. We focus here on red-necked phalaropes Phalaropus lobatus because of the importance of our study site for this species, though the results of our work apply equally to red phalaropes Phalaropus fulicarius, which are also observed in the area. These small, pelagic shorebirds are obligate surface feeders that consume large zooplankton such as Calanus finmarchicus copepods, which have complex life cycles comprised of 6 nauplid stages (NI-NVI) and 5 copepodid stages (CI-CV) in addition to the egg and adult stages. During their autumn southward migration along the Atlantic seaboard, rednecked phalaropes feed on surface aggregations of C. finmarchicus (particularly on the lipid-rich $\mathrm{CV}$ stage) at several sites in the Bay of Fundy, Canada (Mercier \& Gaskin 1985, Brown \& Gaskin 1988, 1989, Hirche 1996). These prey aggregations are important to the energetic balance of migrating phalaropes, allowing them to increase their fat reserves by as much as $30 \%$ in a $2 \mathrm{wk}$ period prior to their departure for waters further south (Mercier 1985). It is important to understand factors controlling prey abundance of this species because the number of birds observed in the Bay of Fundy declined drastically during the late 1980s and has failed to recover since that time. Surveys during the early 1980s produced estimates of nearly 2 million red-necked phalaropes using a small foraging area in the western Bay of Fundy, but phalaropes have since abandoned this foraging area (Finch 1977, Vickery 1978, Morrison et al. 2001, Brown et al. 2005). Recent observations suggest that red-necked phalaropes currently use the Bay of Fundy in smaller numbers during summer months (aggregations of 20000-50000 individuals), and that the largest numbers of red-necked phalaropes typically occur near the Brier Island ledges in the south of the bay (R. Hunnewell pers. comm.). It is unlikely that the observed changes in the abundance of phalaropes using the Bay of Fundy during summer months represents a change in stopover site used by the birds since large aggregations of red-necked phalaropes have not been observed in other locations. Aggregations of the size previously observed in the Bay of Fundy would be easily observable, even from a distance, and the Bay of Fundy still represents the primary staging ground for red-necked phalaropes typically during their southern migration. Declines in surface prey have been suggested to be responsible for the decreased abundance of rednecked phalaropes (Brown et al. 2005), but no published studies have investigated distribution or abundance of prey in foraging areas since the early 1980s.
It has long been suggested that fine-scale oceanographic features are responsible for making Calanus finmarchicus available to predators in surface waters, but early studies in the Bay of Fundy did not quantify the occurrence or effects of these features. For example, Brown (1980) and Brown \& Gaskin (1988) developed, but did not test, hypotheses regarding the oceanographic processes responsible for patterns in the distribution of phalarope prey.

In the present study, we test the following hypothesis initially proposed by Brown (1980): Phalarope foraging habitat is formed when tidal currents interact with underwater ledges to generate fine-scale regions of upwelling which, in turn, transport dense zooplankton aggregation into surface waters. Our specific objectives were to: (1) determine the abundance, species and stage composition of copepods observed in surface waters, and (2) assess how physical oceanography structures the prey field of phalaropes at fine spatial and temporal scales.

\section{MATERIALS AND METHODS}

\section{Study area}

The Bay of Fundy hosts some of the largest tides in the world, with spring tidal ranges of up to $16 \mathrm{~m}$ in some places. The resulting strong tidal currents can structure the prey distribution and foraging habitat of marine predators at fine temporal and spatial scales (e.g. Brown \& Gaskin 1989, Murison \& Gaskin 1989, Baumgartner et al. 2003).

The Brier Island ledges are located at the outer reaches of the Bay of Fundy. Northwest Ledge is $\sim 5 \mathrm{~km}$ northwest of Brier Island (Fig. 1). Bottom topography around the ledges is steep and irregular; depths increase rapidly from $<10 \mathrm{~m}$ over Northwest Ledge to $>200 \mathrm{~m}$ in the Grand Manan Channel, over a horizontal distance of $<3 \mathrm{~km}$. Our surveys were primarily conducted in the vicinity of the Northwest Ledge in order to elucidate the effects of the ledges on surface zooplankton concentration.

\section{Oceanographic sampling}

We conducted oceanographic sampling on 9 survey days between August and September 2007 during both the ebb and flood tide phases. We designed box transects to cover a variety of habitats over and beyond the ledges (Fig. 1), and repeatedly sampled the same locations through time to evaluate 


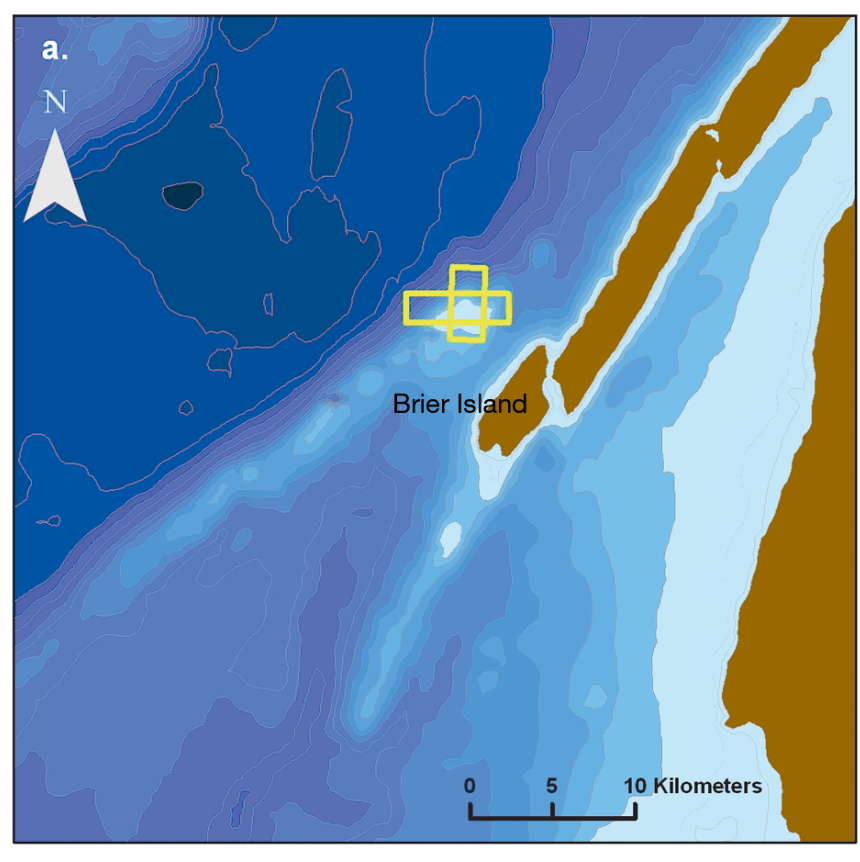

physical and biological parameters throughout the tidal cycle (as in Johnston \& Read 2007). This allowed us to correlate zooplankton samples (detailed in the next section) with physical parameters relative to tidal cycle and bathymetric relief. We sampled sea surface temperature (SST) and current speeds at depth using a $300 \mathrm{kHz}$ RDI Workhorse Sentinel acoustic Doppler current profiler (ADCP) with bottom tracking capability. The ADCP was deployed over the side of a $12 \mathrm{~m}$ boat and the transducer head was positioned $1 \mathrm{~m}$ below the water surface. Survey speed did not exceed $2.6 \mathrm{~m} \mathrm{~s}^{-1}$. The ADCP was set to ping as fast as possible; data were averaged over 1 min intervals and collected in $4 \mathrm{~m}$ bins with a maximum of 60 bins, reflecting the deepest regions surveyed. We collected data using VmDas software and visualized the observations in VmDas and WinADCP and imported them into ArcGIS 9.2 to overlay the ADCP data with bathymetry, zooplankton and phalarope data. A new ADCP file was created for each box transect to avoid obtaining multiple measurements from a given location.

\section{Zooplankton sampling}

We sampled zooplankton concurrent with ADCP surveys and followed the general sampling design of Brown \& Gaskin (1989) to enable us to capture prey items accessible to foraging phalaropes. Zooplankton samples were collected at locations along oceanographic sampling box transects so as to cover a vari-

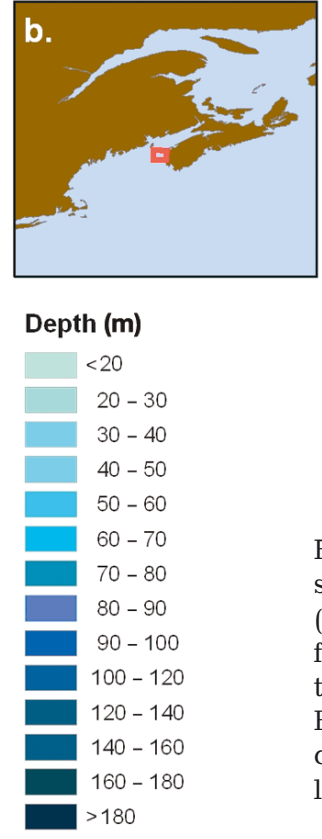

Fig. 1. Study area in Atlantic Canada showing (a) example of box transects (indicated by the yellow boxes) used for oceanographic surveys relative to the bathymetry surrounding the Brier Island ledges (study efforts focused on Northwest Ledge); and (b) location of the study site in the lower Bay of Fundy

ety of bathymetric regions (over and extending beyond the ledge), and were repeatedly sampled at the same locations at different points in the tidal cycle in order to evaluate changes in surface zooplankton concentrations relative to tidal phase.

We employed a net with a $363 \mu \mathrm{m}$ mesh size attached to a metal ring with a diameter of $0.33 \mathrm{~m}$. Tows lasted for $5 \mathrm{~min}$ at a speed of $\sim 1 \mathrm{~m} \mathrm{~s}^{-1}$, during which the net was half submerged in the water. The R-ratio of the net, indicating the ratio of open area of net mesh to the area of the mouth opening of the net, was 10:1, which was suggested in Harris et al. (2000) in order to reduce internal water pressure in the net, and to account for flow rates at higher speeds (though our tow speeds were lower than the speeds of $>1.5 \mathrm{~m} \mathrm{~s}^{-1}$ indicated in Harris et al. 2000). The net was occasionally lifted to avoid floating rockweed. We preserved samples in buffered formalin and transferred them to $70 \%$ ethanol for counting and identification. Zooplankton samples were divided using a Folsom plankton splitter to produce sub-samples of approximately 250 individuals. Zooplankton were counted and identified to species, and Calanus finmarchicus were counted, sexed and identified to life stage using a stereo microscope. All species identifications were verified by Dr. Pat Tester at the National Oceanographic and Atmospheric Administration Southeast Fisheries Science Center Laboratory in Beaufort, NC. C. finmarchicus density was calculated as the number of $C$. finmarchicus copepods $\mathrm{m}^{-3}$ by calculating the volume of water passing through the net as a function of the tow duration, the 
net surface area (assuming that half of the crosssectional surface area of the net was submerged, as described above), and the direction and speed of the boat relative to that of the measured current. After counts and identifications were conducted, we ovendried the samples and weighed them using a balance with a precision of $0.0001 \mathrm{~g}$.

We could not use ADCP backscatter and upwelling velocities to estimate zooplankton densities or identify regions of local upwelling because of problems associated with assessing zooplankton backscatter while steaming (Heywood et al. 1991) and because of noise produced from pitch and roll during boat-based surveys across the ledges. In addition, we were specifically interested in the abundance and distribution of zooplankton that was available to phalaropes in surface waters, which could not be assessed using a hull-mounted ADCP.

\section{Phalarope observations}

Our primary objective was to investigate relationships between oceanographic processes and zooplankton distribution in surface waters, and our box transect surveys were designed to survey a given area repeatedly throughout the tidal cycle. We also collected oceanographic data during boat-based surveys assessing phalarope distribution and abundance on 4 days, and collected 16 zooplankton tows on these survey days. Two observers conducted visual surveys from approximately $6 \mathrm{~m}$ above the water in early $\mathrm{Au}$ gust and mid-September 2007 to estimate the abundance and species composition of phalaropes. In the Bay of Fundy, phalaropes occur in large, ephemeral feeding flocks, so modified survey methods are required to generate estimates of phalarope abundance and species composition. Tracks were initiated at the north or south end of the ledges, and were conducted across the ledges using a saw-tooth pattern until birds were observed. We decreased speed when flocks of phalaropes were encountered and maneuvered the boat alongside the flocks to obtain accurate counts and to confirm species identification. In late summer, red and red-necked phalaropes occur in large mixed aggregations in non-breeding plumage and can be difficult to distinguish. Surveys on these days yielded 82 sightings of phalaropes, comprising more than 13000 birds, with concurrent oceanographic data. Survey tracks were divided into $1 \mathrm{~km}$ bins in ArcGIS, and phalarope counts in grid cells were analyzed relative to oceanographic predictor variables using multivariate analyses (see next section).

\section{Analysis}

We interpolated depth estimates from ADCP surveys to provide a comprehensive bathymetric coverage of the study area. We produced continuous rasters of SST, average current speed and depth by interpolating short-term averaged data (1 $\mathrm{min})$ in ArcGIS 9.2 using ordinary kriging interpolation in the spatial analyst extension. The bathymetric raster was then used to generate a continuous coverage of distance to the $20 \mathrm{~m}$ depth contour, which we used as a metric of distance to the Northwest Ledge. We used depth rasters to create grids of depth gradients (percent rise) using the slope function in spatial analyst. All interpolated rasters had a pixel size of $50 \mathrm{~m}$. Before including variables in our statistical analyses, we examined our data for co-linearity. Variables with a significant Pearson's correlation coefficient of 0.5 or greater were not included within the same model.

We used generalized additive models (GAMs) to model zooplankton and phalarope abundance relative to oceanographic parameters. GAMs are nonparametric extensions of linear regression models. These additive models consist of the sum of smooth functions describing the covariates, which replace the linear predictors of covariates used in linear regression models (Hastie \& Tibshirani 1990). A link function is used to relate response variables to a smoothed function of the explanatory variables. In comparison to linear models, GAMs allow a wider range of response curves to be modeled and are better suited to evaluate highly non-linear relationships between response and explanatory variables. These attributes are particularly useful in ecological studies (see Yee \& Mitchell 1991, Guisan et al. 2002). Selecting an appropriate level of smoothing is an important step in developing a GAM, and can be achieved by using the concept of the effective degrees of freedom (Guisan et al. 2002). We constructed GAMs using cubic spline smoothers with 3 or fewer degrees of freedom to avoid over-fitting the models while assessing relationships between copepod density, total zooplankton biomass or phalarope abundance and the following predictor variables: SST, SST gradient, daily SST anomaly (i.e. deviance of a given SST measurement from the daily mean SST over all tracks lengths), distance to $20 \mathrm{~m}$ contour, depth gradient, current speed and time since slack low tide. This analysis was intended to capture the effects of current speed and bathymetry on surface distributions of copepods that are more typically observed at depths of more than $50 \mathrm{~m}$ during daylight hours, so we used current speed 
throughout the water column in this analysis. We constructed models both for counts and dry mass values of zooplankton tows, as well as the proportion of all copepods comprised of Calanus finmarchicus, standardized by the tow volume to account for differences due to increased water flow. We assessed the normality of counts and dry mass values using Q-Q plots and Anderson-Darling normality tests. We employed a Gaussian distribution to evaluate dry mass values, which were log-transformed to meet assumptions of normality. We analyzed copepod and phalarope count data using a quasi-Poisson distribution due to over-dispersion of the data. For all GAM models, we conducted variable selection using backwards stepwise regression model selection and selected the model with the lowest generalized cross-validation (GCV) value as described in Wood \& Augustin (2002). We assessed goodness-of-fit using adjusted $\mathrm{R}^{2}$ values. Non-significant values were removed from the final model. To examine the temporal structure of the copepod data, we assessed the relationship between volumecorrected copepod counts and tidal phase (hours since slack low tide).

We used Moran's I correlograms (Legendre \& Legendre 1998) to identify potential effects of spatial autocorrelation in model residuals. Moran's I indicates the degree of spatial autocorrelation of data from -1 to 1 , and can be used to determine whether significant autocorrelation is present. Negative values of Moran's I indicate segregation, while positive values indicate aggregation (Fortin et al. 1989). We assessed spatial autocorrelation in model residuals using Moran's I correlograms for all zooplankton and phalarope models and assessed significance using 1000 permutations (Bjornstad \& Falck 2001). We used lag distances of $500 \mathrm{~m}$ for zooplankton models, reflecting the shortest distance travelled between zooplankton tows, and $1000 \mathrm{~m}$ for phalarope models, representing the bin size used to assess phalarope counts, up to a distance of $10 \mathrm{~km}$. If significant spatial autocorrelation was observed in model residuals at any distance lag, we fitted generalized additive mixed models (GAMMs) with an AR1 autoregressive correlation structure (Dormann et al. 2007). We then compared GAM and GAMM models to determine whether autocorrelation influenced the model results.

We conducted all statistical analyses in the R statistical package (version 2.9) using the 'mgcv', 'ncf', and 'stats' packages to evaluate GAMs and GAMMs, Moran's I correlograms, and Pearson's correlation coefficients, respectively.

\section{RESULTS}

We conducted 133 zooplankton tows on the Brier Island ledges, and 117 tows with concurrent oceanographic data (16 tows were conducted during phalarope surveys). On average, Calanus finmarchicus made up $54 \%$ of the copepod species collected. There was a high degree of variation between samples, with $C$. finmarchicus ranging from 4.5 to $95.5 \%$ of copepods and from 0.01 to 200.6 ind. $\mathrm{m}^{-3}$, and dry biomass of zooplankton samples ranging from 0.01 to $13.8 \mathrm{mg} \mathrm{m}^{-3}$. Stages CIV to CVI C. finmarchicus dominated zooplankton tows, making up $90.2 \%$ of all C. finmarichus individuals. The average density of total and stage CV C. finmarchicus (ind. $\mathrm{m}^{-3}$ ) peaked in late August. Due to the large variation in abundance and biomass, we also examined trends in $C$. finmarchicus through time using maximum observed values and found that the maximum density of stage CV C. finmarchicus (ind. $\mathrm{m}^{-3}$ ) also peaked in late August (Fig. 2).

We analyzed separate models using daily SST anomalies and SST values as predictor variables of copepod density and phalarope counts because these terms provided different means of examining the importance of temperature and were highly correlated (Pearson's correlation, $r=0.74, \mathrm{p}<0.001$ ). Variables included in the optimal model describing total Calanus finmarchicus density were current speed, SST, distance to ledge, time since slack low tide, and depth gradient (Table 1). The density of $C$. finmarchicus was strongly and negatively correlated with distance to ledge (20 m contour) and SST, and positively correlated with current speed. The highest densities of $C$. finmarchicus were observed at $\sim 3 \mathrm{~h}$ into the flood tide, and at intermediate or high values of depth gradient (Fig. 3). To illustrate tempo-

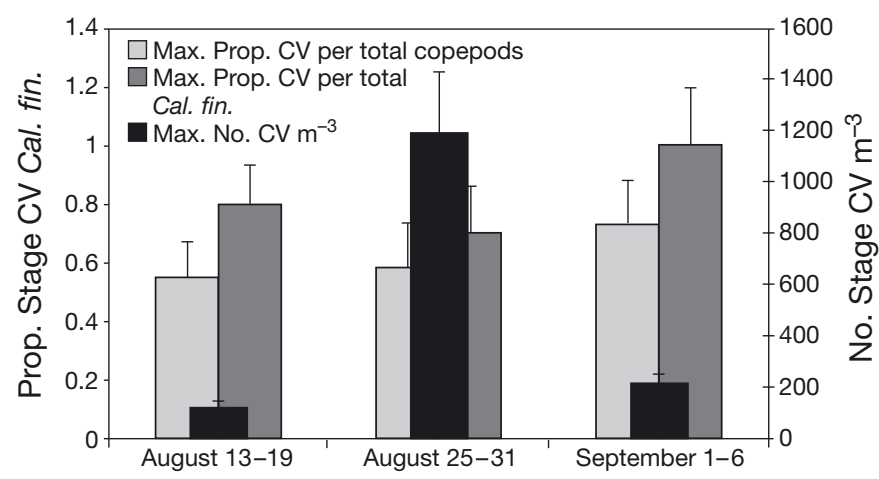

Fig. 2. Maximum proportion and density of stage $\mathrm{CV}$ Calanus finmarchicus by survey week $( \pm 1 \mathrm{SD})$. Stage CV is shown both as a proportion of total copepods and as a proportion of total C. finmarchicus (indicated as Cal. fin.) 
Table 1. Variables included in best fit models for total Calanus finmarchicus, stage CV C. finmarchicus, C. finmarchicus as a proportion of total copepods, dry zooplankton biomass and phalarope counts. D20 = distance to 20 m contour; SST = sea surface temperature; $\Delta$ depth $=$ depth gradient (percent rise)

\begin{tabular}{|c|c|c|c|c|c|c|}
\hline $\begin{array}{l}\text { Dependent } \\
\text { variable }\end{array}$ & $\begin{array}{l}\text { Variables used } \\
\text { in model }\end{array}$ & Estimate $\pm \mathrm{SE}$ & $t$ & $\mathrm{p}$ & $\begin{array}{c}\text { Deviance } \\
\text { explained (\%) }\end{array}$ & $\mathrm{R}^{2}$ \\
\hline $\begin{array}{l}\text { C. finmarchicus } \\
\text { density } \\
\left(\text { ind. } \mathrm{m}^{-3} \text { ) }\right.\end{array}$ & $\begin{array}{l}\text { (intercept) } \\
\text { D20 } \\
\text { Current speed } \\
\text { SST } \\
\text { Time since low tide } \\
\Delta \text { depth }\end{array}$ & $3.02 \pm 0.33$ & 9.15 & $\begin{array}{l}1.07 \times 10^{-12} \\
3.59 \times 10^{-5} \\
1.65 \times 10^{-2} \\
2.57 \times 10^{-7} \\
1.14 \times 10^{-2} \\
1.90 \times 10^{-3}\end{array}$ & 71.0 & 0.68 \\
\hline $\begin{array}{l}\text { Stage } \mathrm{CV} \\
\text { C. finmarchicus } \\
\text { density } \\
\left(\text { ind. } \mathrm{m}^{-3} \text { ) }\right.\end{array}$ & $\begin{array}{l}\text { (intercept) } \\
\text { D20 } \\
\text { Current speed } \\
\text { SST }\end{array}$ & $2.54 \pm 0.38$ & 6.78 & $\begin{array}{c}2.62 \times 10^{-9} \\
0.031 \\
0.0012 \\
0.0064\end{array}$ & 57.3 & 0.37 \\
\hline $\begin{array}{l}\text { C. finmarchicus } \\
\text { as a proportion } \\
\text { of total copepods }\end{array}$ & $\begin{array}{l}\text { (intercept) } \\
\text { D20 } \\
\text { Current speed } \\
\text { SST }\end{array}$ & $1.72 \pm 0.084$ & 20.54 & $\begin{array}{c}<2.00 \times 10^{-16} \\
1.27 \times 10^{-3} \\
5.95 \times 10^{-2} \\
1.05 \times 10^{-2}\end{array}$ & 33.3 & 0.29 \\
\hline $\begin{array}{l}\text { Dry mass of } \\
\text { zooplankton samples } \\
\left(\mathrm{mg} \mathrm{m}^{-3}\right)\end{array}$ & $\begin{array}{l}\text { (intercept) } \\
\text { D20 } \\
\text { SST }\end{array}$ & $-7.93 \pm 0.14$ & -57.79 & $\begin{aligned}<2.00 \times 10^{-16} \\
2.39 \times 10^{-5} \\
2.42 \times 10^{-3}\end{aligned}$ & 36.6 & 0.34 \\
\hline Phalarope counts & $\begin{array}{l}\text { (intercept) } \\
\text { Current speed } \\
\text { SST } \\
\text { D20 }\end{array}$ & $2.74 \pm 0.34$ & 8.08 & $\begin{array}{l}5.07 \times 10^{-13} \\
4.00 \times 10^{-3} \\
9.80 \times 10^{-10} \\
7.61 \times 10^{-4}\end{array}$ & 51.0 & 0.30 \\
\hline
\end{tabular}

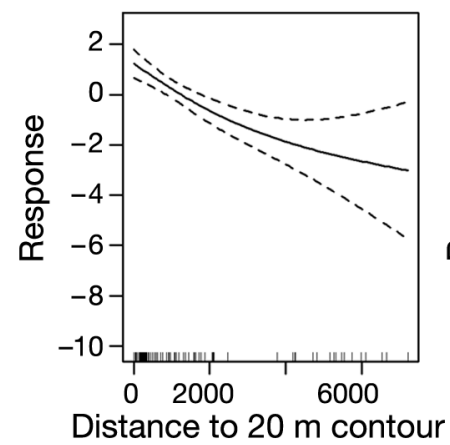

(m)

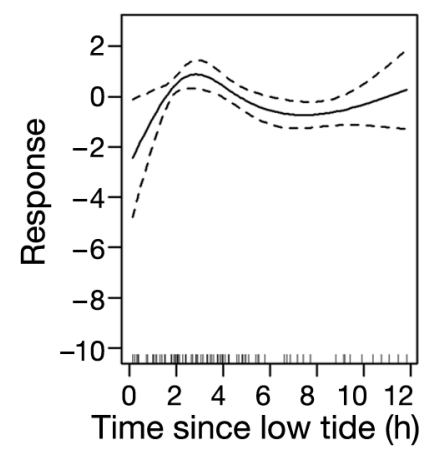

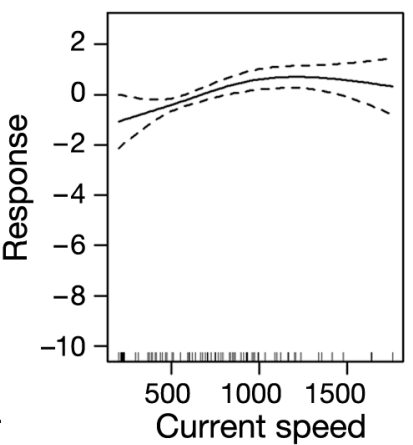

$\left(\mathrm{m} \mathrm{s}^{-1}\right)$

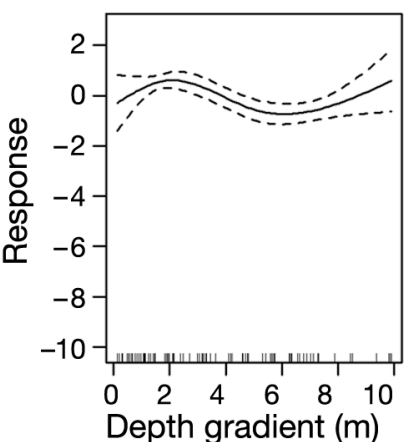

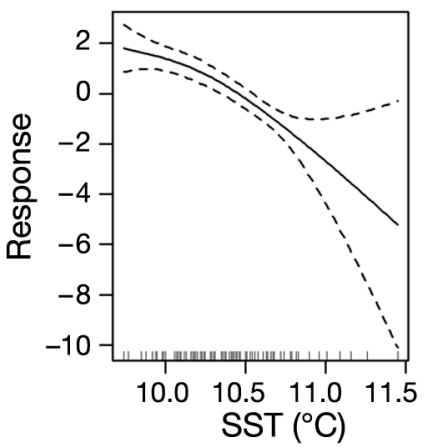

Fig. 3. Response curves for generalized additive models (GAMs) of Calanus finmarchicus density (ind. $\mathrm{m}^{-3}$ ) relative to significant oceanographic predictor variables. Dashed lines $= \pm 2 \mathrm{SE}_{\text {; }}$ rug plots $=$ distribution of data along the $x$-axis 
ral trends in the abundance of C. finmarchicus, fluctuations in total $C$. finmarchicus density at a given location on Northwest Ledge are shown throughout the tidal cycle relative to SST and current speed in Fig. 4.
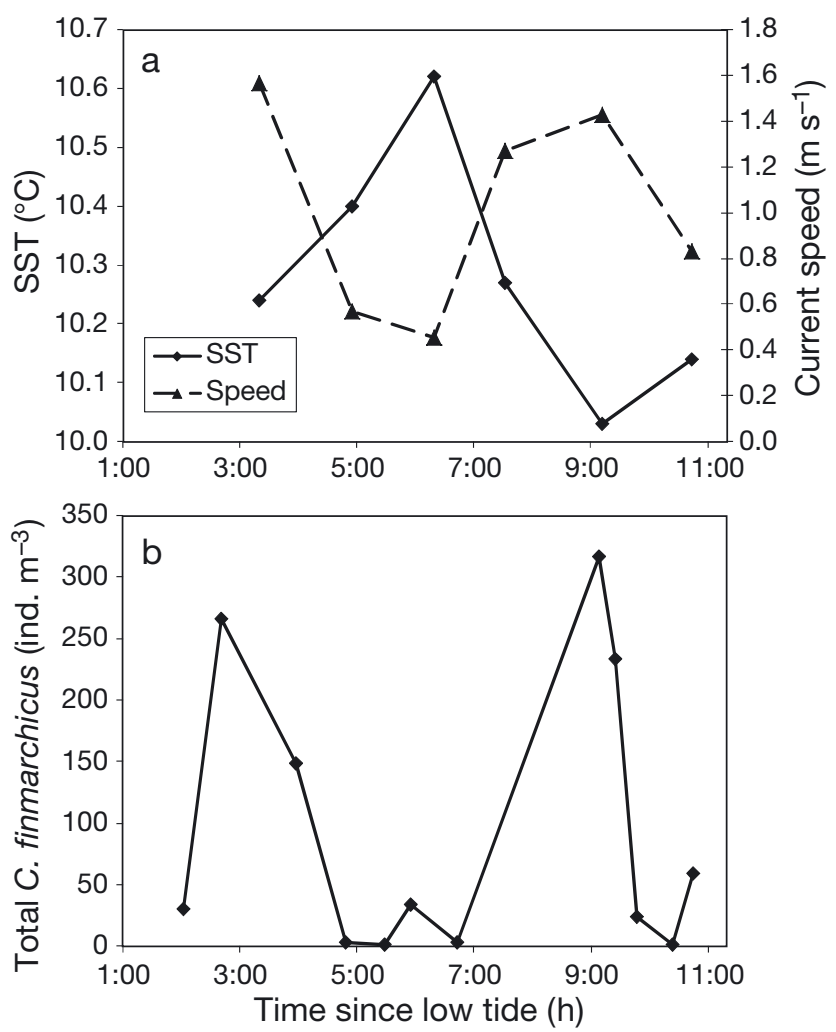

Fig. 4. Example of (a) sea surface temperature (SST) and current speed relative to time of tidal cycle (sampled at a central point on Northwest Ledge with a depth of $30 \mathrm{~m}$ on 30 August 2007). Note that current speeds measured at this location during slack high tide were $>0.40 \mathrm{~m} \mathrm{~s}^{-1}$. Current speeds measured in other locations during slack high tide reached approximately $0.05 \mathrm{~m} \mathrm{~s}^{-1}$. (b) The density of total Calanus finmarchicus is shown relative to time since low tide for the same day
For stage CV density and the proportion of Calinus finmarchicus in zooplankton tows, distance to ledge, current speed and SST were the best predictors (Table 1). In both models, distance to ledge $(20 \mathrm{~m}$ depth contour) showed a strong negative relationship with the model response, while the model response differed somewhat for the models evaluating CV density and the proportion of C. finmarchicus among copepods. The density of stage CV C. finmarchicus increased with current speed and leveled off at current speeds of $\sim 1 \mathrm{~m} \mathrm{~s}^{-1}$, while the proportion of C. finmarchicus increased with current speed throughout the range of current speeds measured. Both stage CV density and the proportion of C. finmarchicus among copepods showed a strong negative relationship with SST (Figs. 5 \& 6). SST and distance to ledge were the only significant predictors of dry zooplankton biomass (Table 1) and dry zooplankton biomass was negatively correlated with both of these variables (Fig. 7). Adjusted $\mathrm{R}^{2}$ values for the models ranged from intermediate $(0.37$ for stage $\mathrm{CV}$ C. finmarchicus density, 0.29 for the proportion of C. finmarchicus among copepods, and 0.30 for dry zooplankton biomass) to high (0.68 for total C. finmarchicus density), indicating a good model fit. For all zooplankton models, correlograms indicated no significant spatial autocorrelation in model residuals.

Distance to the $20 \mathrm{~m}$ contour was an important predictor value in all of the zooplankton GAM models, so we used this parameter to examine the spatial and temporal extent of the effects of the ledges on surface zooplankton densities. Raw data plots of the number of Calanus finmarchicus $\mathrm{m}^{-3}$ vs. distance to the $20 \mathrm{~m}$ contour suggested that we would expect to observe measurable effects of the physical environment on the abundance of zooplankton at the surface at distances of $1100 \mathrm{~m}$ from the ledges (defined by the $20 \mathrm{~m}$ contour). To examine whether this distance
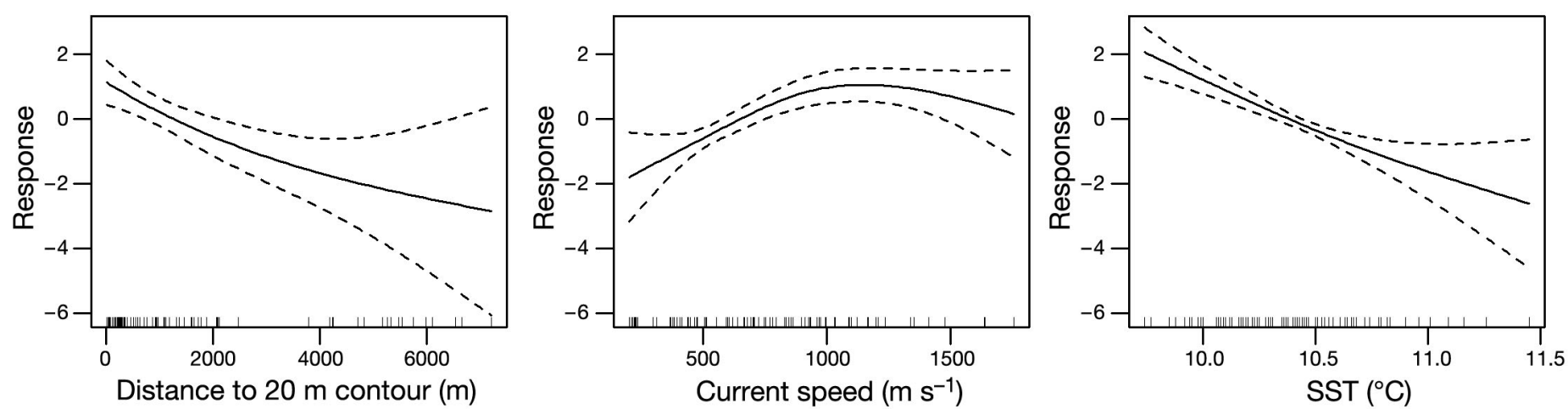

Fig. 5. Response curves for generalized additive models (GAMs) of Calanus finmarchicus stage CV density (ind. $\mathrm{m}^{-3}$ ) relative to significant oceanographic predictor variables. Dashed lines $= \pm 2 \mathrm{SE}$, rug plots $=$ distribution of data along the $x$-axis 

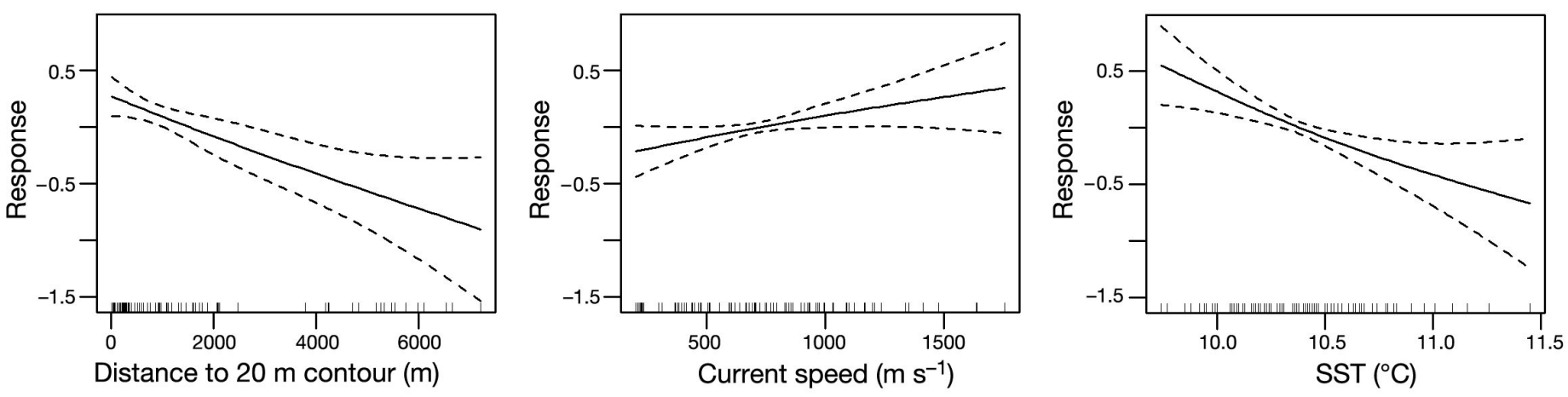

Fig. 6. Response curves for generalized additive models (GAMs) of Calanus finmarchicus as a proportion of total copepods relative to significant oceanographic predictor variables
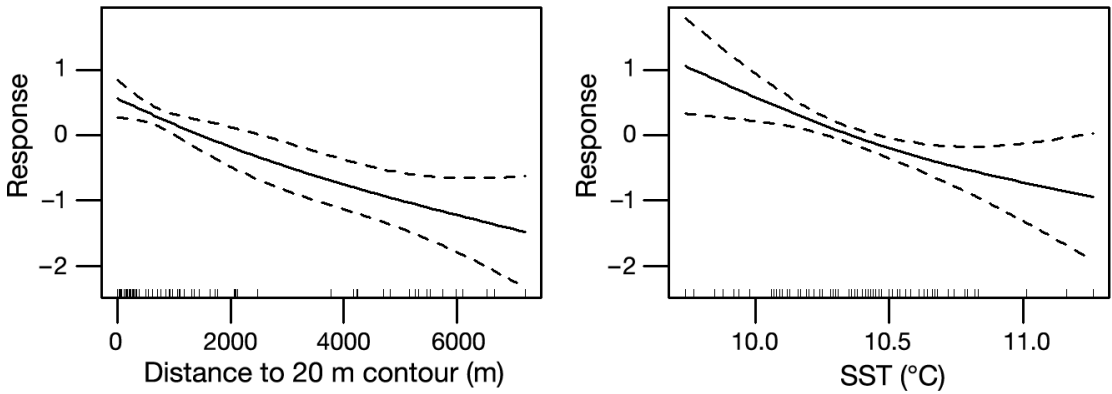

Fig. 7. Response curves for generalized additive models (GAMs) of dry zooplankton biomass $\left(\mathrm{mg} \mathrm{m}^{-3}\right)$ relative to significant oceanographic predictor variables. Dashed lines $= \pm 2 \mathrm{SE}$; rug plots $=$ distribution of data along the $x$-axis appropriately captured patterns in the abundance of C. finmarchicus, we compared temporal patterns in the abundance of $C$. finmarchicus collected at locations both within and beyond $1100 \mathrm{~m}$ of Northwest Ledge (69 samples were collected within this dis-

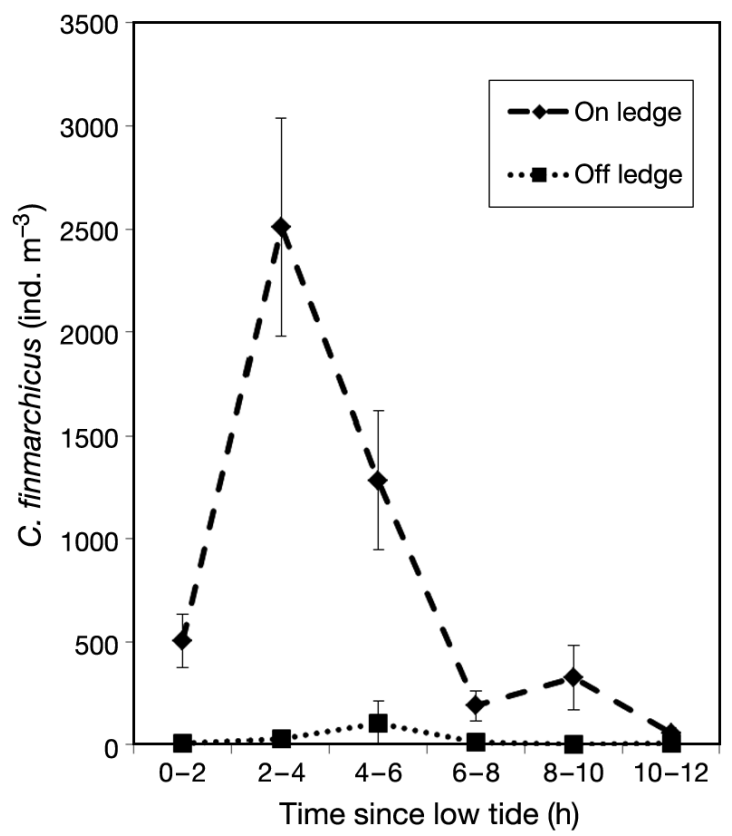

Fig. 8. Maximum Calanus finmarchicus density (ind. $\mathrm{m}^{-3}$ ) by tidal phase on Northwest Ledge (within $1100 \mathrm{~m}$ of the $20 \mathrm{~m}$ depth contour) and off of Northwest Ledge tance, while 48 were collected beyond this distance). Both the average and maximum abundance of $C$. finmarchicus were higher within $1100 \mathrm{~m}$ of Northwest Ledge, particularly during the flood tide phase. Due to the high degree of variation between samples as described above, we focused on the maximum abundance of $C$. finmarchicus throughout the tidal phase both within and beyond $1100 \mathrm{~m}$ (Fig. 8). Given the observed relationship between current speed and surface densities of $C$. finmarchicus and zooplankton biomass, we expected that broader temporal trends in current speed might also have important effects on the abundance of $C$. finmarchicus in surface waters. Fig. 9 shows the maximum observed abundance of total $C$. finamarchicus and stage CV C. finmarchicus relative to the average tidal amplitude at Brier Island (determined from tidal charts for Westport, NS). Maximum tidal amplitude peaked in the week of 25-31 August, as did the maximum abundance of total $C$. finamarchicus and stage CV C. finmarchicus in surface waters.

The GAM describing phalarope counts performed relatively well $\left(\mathrm{R}^{2}=0.30\right)$ and indicated that the best model included current speed, SST, SST gradient and distance to ledge. Correlograms indicated significant positive spatial autocorrelation in phalarope model residuals at a distance lag of $\sim 8000 \mathrm{~m}$. Consequently, GAMMs were constructed using an autocorrelated correlation structure, and results indicated 


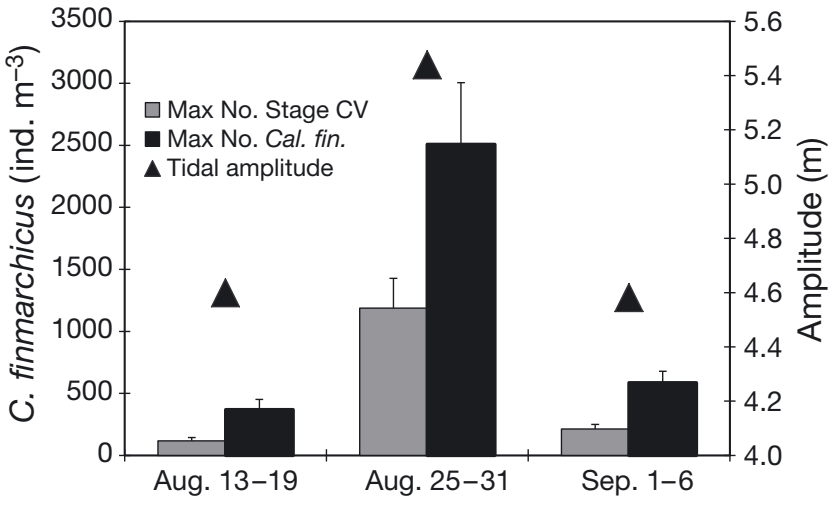

Fig. 9. Maximum density of total Calanus finmarchicus and stage CV C. finmarchicus (ind. $\mathrm{m}^{-3}$ ) by survey week relative to tidal amplitude at the Brier Island ledges

that SST gradient was not a significant predictor variable in the mixed model. The full mixed model excluding this variable found no significant residual spatial autocorrelation. The resulting mixed model for phalarope counts is described in Table 1. Phalaropes were most abundant at low to mid values of current speed, and at intermediate values of distance to ledge (Fig. 10), which differed from the zooplankton models. As with surface zooplankton densities, phalaropes were found to be more abundant in regions of low SST, with the highest phalarope aggregations occurring at temperatures of less than $10.5^{\circ} \mathrm{C}$ (Fig. 10).

\section{DISCUSSION}

Calanus finmarchicus and other zooplankton are physically forced into surface waters at the Brier Island ledges due to interactions between strong tidal currents and steep bathymetric gradients. Our findings build on previous studies, which demon- strated high surface densites of C. finmarchicus and emphasized the importance of weed slicks in aggregating zooplankton in this region, but did not examine temporal variation in zooplankton densities or zooplankton counts within tidal phases (Brown \& Gaskin 1989). Our models highlighted the importance of tidally driven upwelling in structuring zooplankton distributions in surface waters. Both the total density of $C$. finmarchicus and the proportion of this species to total copepods were strongly correlated with SST, distance to the ledge, and current speed. Together, stages CIV to CVI made up $90.2 \%$ of the total C. finmarchicus in surface zooplankton tows over the Brier Island ledges, although these stages are typically found in much deeper water during daylight hours in the Bay of Fundy (Baumgartner et al. 2003). Stage CV C. finmarchicus are a particularly important energy resource for phalaropes, and this stage typically occurs at depths of 50 to $>100 \mathrm{~m}$ during daylight hours (Baumgartner et al. 2003).

The density of Calanus finmarchicus showed a significant negative relationship with SST and a positive relationship with current speed, indicating that local upwelling occurring during periods of high current speed creates aggregations of $C$. finmarchicus in surface waters, particularly on the flood tide. Observations of water temperature at depth in the Bay of Fundy, which typically declines from surface temperatures of $10.5-11^{\circ} \mathrm{C}$ to $10^{\circ} \mathrm{C}$ at depths of $40-50 \mathrm{~m}$ during August and September, further support the hypothesis that tidal forcing aggregates zooplankton in surface waters. C. finmarchicus stages typically found at or below these depths (Baumgartner \& Mate 2003) were particularly prevalent in surface waters with temperatures of $\sim 10^{\circ} \mathrm{C}$ or lower. Total dry zooplankton biomass, representing all zooplankton species observed in surface waters, also showed similar rela-
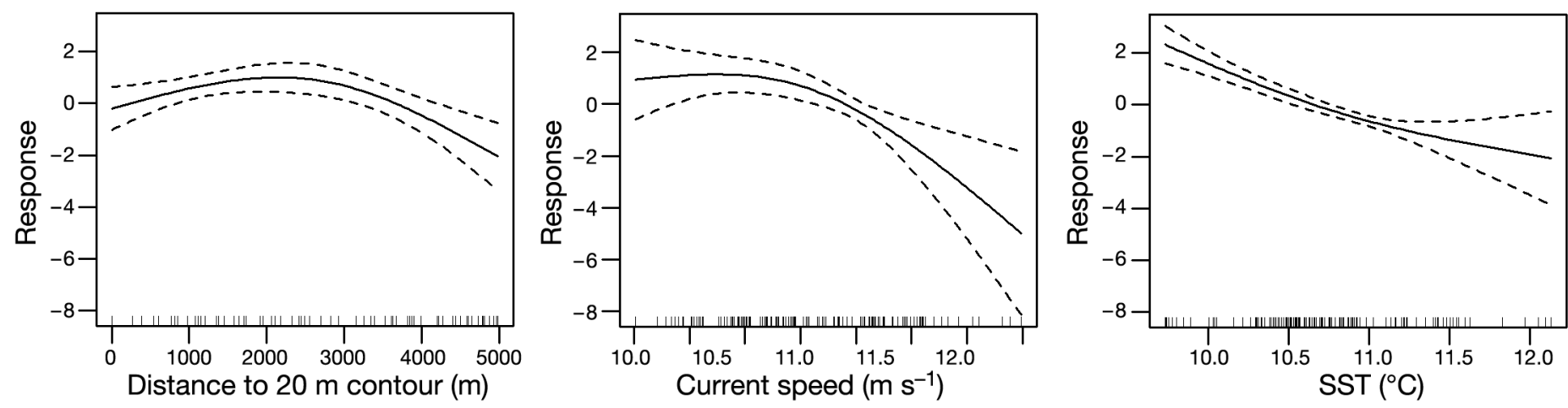

Fig. 10. Response curves for generalized additive models (GAMs) of phalarope counts relative to significant oceanographic predictor variables. Dashed lines $= \pm 2 \mathrm{SE}_{\text {; }}$ rug plots $=$ distribution of data along the $x$-axis 
tionships with oceanographic processes over the Brier Island ledges. Taken together, therefore, our observations support the original hypothesis proposed by Brown (1980).

Model results and zooplankton measurements on the ledges (Figs. 3 \& 8) indicated that the abundance of Calanus finmarchicus was highest during the flood tide phase. ADCP data indicated that during this tide phase, the northwestern part of the ledge was dominated by a stronger eastward flow than elsewhere on the ledge; and thus waters in this region pass over a very steep bathymetric gradient, resulting in strong vertical mixing. In addition, this causes a convergence of strong tidal currents on this part of the ledge. Both of these factors likely lead to increased densities of zooplankton in surface waters at this location during the flood tide.

Our models also indicated that both phalaropes and Calanus finmarchicus were more abundant in areas of low SST (e.g. Figs. 3, 4b, 5, 6, 7 \& 10). Phalaropes are visual predators (Mercier 1983), and it is possible that the birds may be able to identify surface manifestations of upwelling to help locate prey aggregations. Interestingly, phalaropes were associated with regions of lower current speed and intermediate distances from the ledge, but maximum C. finmarchicus distributions occurred in close proximity to the ledge and at high current speeds. These findings are consistent with our visual observations of phalaropes near the ledge. When current speeds were highest, the surface waters immediately over the ledge were quite turbulent, and current speeds tended to be higher immediately over the ledges (authors' unpubl. obs.). As visual predators, phalaropes may require relatively calm waters to locate individual zooplankton prey, and thus avoid rough waters immediately over the ledges. In addition, Brown (1980) hypothesized that cool waters upwelled over the ledges drift downstream and create convergence streaks, where zooplankton and flotsam are aggregated at the surface as they sink, and that phalaropes might follow these upwelled patches of water. This hypothesis, along with our observation of rough waters over the ledges when cold water is upwelled, could explain the differences in the oceanographic parameters associated with phalarope and copepod abundance. Studies quantifying the fine-scale movements of phalaropes throughout the tidal cycle are logistically challenging to undertake, particularly due to the small size of the birds ( 30 $\mathrm{g}$ in mass) but would improve our understanding of phalarope habitat use in this area considerably. In the future, lighter GPS tags sam- pling at a high spatial resolution may allow us to examine these trends in detail.

If phalaropes avoid rough waters immediately above the ledges or use weed slicks as a visual cue to detect prey aggregations in cool waters that have drifted downstream, one would expect a negative relationship between phalarope abundance and both SST and current speed, as observed. Similarly, one would expect to see maximum values of phalarope abundance to occur at intermediate distances from the ledge, as indicated by our model. Copepod densities would be expected to be high in these downstream regions of upwelled water, although not as high as in upwelling regions immediately above the ledge, as reflected in the copepod GAM models. Future studies following patches of low SST through time, or those incorporating fine-scale optical plankton counter (OPC) surveys with concurrent oceanographic surveys to provide continuous measurements of zooplankton distributions, would allow zooplankton to be evaluated relative to drifting patches of upwelled water. However, OPC measurements would not provide measurements in the upper centimeters of the water column, which are accessible to phalaropes; therefore, surface zooplankton tows should be included when assessing prey availability for this species of concern. Studies linking movements of cool water patches through time with the aggregation of surface zooplankton and formation of weed slicks, though logistically challenging, would be particularly relevant to studies of phalarope foraging.

Our models suggested that proximity to the Brier Island ledges, current speed, SST and tidal state were significant predictors of the abundance of Calanus finmarchicus. These findings demonstrate that the ledges affect the abundance of surface $C$. finmarchicus densities at fine spatial and temporal scales. Thus, the location of samples collected relative to the ledge and the timing of the tidal phase are important factors to consider during future efforts seeking to quantify available phalarope prey in this migratory stopover region. This would allow future studies to make comparisons with the results of the present study, and to further sampling efforts in phalarope foraging habitat. The significant effects of oceanographic processes on zooplankton abundance in both space and time highlights that these underlying processes must be considered before patterns in zooplankton or phalarope abundance can be understood over both short and long time scales.

Oceanographic processes in other locations within the Bay of Fundy also create dynamic foraging habi- 
tat for phalaropes. Phalaropes likely move between different foraging patches over different tidal phases. For example, we observed phalaropes feeding on weed 'slicks', likely associated with convergence fronts (Brown 1980), south of Brier Island during low tide - when convergence between in- and outflowing tidal currents would be expected. Similarly, observations of foraging phalaropes from aerial survey data suggest that these birds are associated with bathymetric gradients and features in other locations within the Bay of Fundy (R. Hunnewell unpubl. obs.). Evaluating surface zooplankton distributions in these areas would provide a more complete picture of the prey field currently available to foraging phalaropes. Ongoing bay-wide aerial and boat-based surveys in the Bay of Fundy by the Manomet Center for Conservation Science will provide a more comprehensive picture of present-day phalarope habitat use within this region.

We emphasize that the physical mechanism influencing the distribution of Calanus finmarchicus is one of direct tidal forcing and physical advection. This differs from the mechanism of prey aggregation in many oceanographic features, in which increases in primary productivity are followed by time-lagged effects at successive trophic levels of the food web (e.g. Croll et al. 2005). The effects of biophysical interactions appeared to be most pronounced within $1100 \mathrm{~m}$ of the Brier Island ledges, but continuous sampling would be required to assess the spatial dimensions of zooplankton patches. Again, optical plankton counters would be useful in further assessing fine-scale zooplankton patch dynamics in this area.

In recent research in the Bay of Fundy, maximum depth-integrated densities of stage CV Calanus finmarchicus observed by Michaud \& Taggart (2007) were similar to those in the present study $(\sim 1200$ Stage CV C. finmarchicus $\mathrm{m}^{-3}$ in both cases). However, it is unclear how, or to what extent, the abundance and species composition of zooplankton in the Bay of Fundy may have changed since large phalarope aggregations were observed in the 1980s. Longterm zooplankton sampling studies in the Gulf of Maine have indicated a dramatic change in zooplankton community structure during the late 1980s. C. finmarchicus in the Gulf of Maine declined between 1989 and 1991 and remained low throughout the 1990s, likely due to changes in circulation associated with the North Atlantic Oscillation (Pershing et al. 2005). These changes in C. finmarchicus are thought to have influenced the abundance of another predator foraging primarily on this zooplankton species, the North Atlantic right whale Eubalaena glaci- alis (Greene \& Pershing 2004) and may have played a role in the decline in red-necked phalaropes using the Bay of Fundy as a migratory stopover. Rednecked phalaropes have not been reported in such large aggregations during summer months since studies by Mercier (1983) and Brown \& Gaskin (1988, 1989), despite increases in $C$. finmarchicus in the Gulf of Maine in recent years (Pershing et al. 2005). This suggests that the decreases in red-necked phalaropes in the Bay of Fundy may reflect population declines rather than shifts in habitat use.

Several studies have found associations between foraging seabirds and tidally-driven oceanographic features, and some have demonstrated that temporal components of these features were important factors influencing seabird abundance and distribution (Braune \& Gaskin 1982, Zamon 2003). However, the mechanism by which these features create regions of increased prey for foraging seabirds was not investigated specifically. Independent of seabird research, many studies have evaluated processes creating aggregations of zooplankton and fish relative to different bathymetric features such as continental shelf breaks, banks, seamounts and canyons (e.g. Werner et al. 1993, Townsend \& Pettigrew 1996, Genin 2004). Several studies have suggested that bathymetric features have important effects on seabird foraging habitat (e.g. Coyle et al. 1992, Hunt et al. 1998), though few studies of seabirds in relation to bathymetric features have included surveys of prey distribution. Hunt et al. (1998) demonstrated that crested, least, and parakeet auklets show species-specific patterns, foraging in regions of shallow passes in the Aleutian Islands that are upstream, downstream, and on top of the passes, respectively. Spatial differences in the location of the different prey species of these auklets were found to drive this pattern of differential habitat use, and increased tidal speed was associated with an increase in the number of auklets foraging in the passes. While biological oceanographers have made substantial progress in understanding how biophysical interactions within different oceanographic features structure biological patterns (e.g. Alldredge \& Hamner 1980, Wolanski \& Hamner 1988, Tremblay \& Sinclair 1992, Genin 2004), our understanding of how the effects of these interactions are transferred up the food web to foraging seabirds could be improved by studies such as that of Hunt et al. (1998) which connect physical oceanographic processes with distributions of both foraging seabirds and their prey.

In conclusion, our results support the hypothesis of Brown (1980) and demonstrate that strong tidal cur- 
rents generate zooplankton-rich upwelling hotspots above the ledges at fine temporal and spatial scales. We documented the zooplankton prey field available to phalaropes foraging in the Brier Island region of the Bay of Fundy and demonstrated the importance of physical forcing in structuring zooplankton abundance and species composition at fine spatial and temporal scales. At broader scales, we observed high variation in the density of surface zooplankton samples due to the extremely dynamic nature of this area, demonstrating the need for careful survey design and methods in future assessments of zooplankton distributions in this region, particularly in efforts to quantify phalarope prey. It is particularly important to capture this source of variation in the distribution of prey, so that we can accurately assess the potential drivers of the demography of rednecked phalaropes in the Bay of Fundy.

Acknowledgements. We thank R. Hunnewell and the Manomet Center for Conservation Studies for assistance in the field and for providing phalarope data for the 2007 field season. We are grateful to M. O'Brien and E. J. Rayner for their assistance during field studies, and to D. Forward, P. Tester and B. Waggett for providing advice on zooplankton sampling and identification. M. Bowers and J. Moore are thanked for assistance with weighing zooplankton samples and providing statistical advice, respectively. Funding for this project was provided by the National Geographic Society and the Oak Foundation.

\section{LITERATURE CITED}

Alldredge AL, Hamner WM (1980) Recurring aggregation of zooplankton by a tidal current. Estuar Coast Mar Sci 10: 31-37

Baumgartner MF, Mate BR (2003) Summertime foraging ecology of North Atlantic right whales. Mar Ecol Prog Ser 264:123-135

Baumgartner MF, Cole TVN, Clapham PJ, Mate BR (2003) North Atlantic right whale habitat in the lower Bay of Fundy and on the SW Scotian Shelf during 1999-2001. Mar Ecol Prog Ser 264:137-154

Bjornstad ON, Falck W (2001) Nonparametric spatial covariance functions: estimation and testing. Environ Ecol Stat 8:53-70

Braune BM, Gaskin DE (1982) Feeding ecology of nonbreeding populations of Larids off Deer Island, New Brunswick. Auk 99:67-76

Brown RGB (1980) Seabirds as marine animals. In: Winn HE, Burger J, Olla BL (eds) Behaviour of marine animals: marine birds. Plenum Press, New York, NY

Brown RGB, Gaskin DE (1988) The pelagic ecology of the grey and red-necked phalaropes Phalaropus fulicarius and P. lobatus in the Bay of Fundy, eastern Canada. Ibis 130:230-250

Brown RGB, Gaskin DE (1989) Summer zooplankton distributions at the surface of the outer Bay of Fundy, eastern Canada. Can J Zool 67:2725-2730

Brown S, Duncan C, Chardine J, Howe M (2005) Red- necked phalarope research, monitoring, and conservation plan for the Northeastern US and Maritimes Canada (version 1.0). Manomet Center for Conservation Sciences, Manomet, MA

Coyle KO, Hunt GL Jr, Decker MB, Weingartner TJ (1992) Murre foraging, epibenthic sound scattering and tidal advection over a shoal near St. George Island, Bering Sea. Mar Ecol Prog Ser 83:1-14

> Croll DA, Marinovic B, Benson S, Chavez FP, Black N, Ternullo R, Tershy BR (2005) From wind to whales: trophic links in a coastal upwelling system. Mar Ecol Prog Ser 289:117-130

> Dormann CF, McPherson JM, Araújo MB, Bivand R and others (2007) Methods to account for spatial autocorrelation in the analysis of species distributional data: a review. Ecography 30:609-628

Finch EW (1977) Northeastern maritime region. Am Birds 31:225-231

Fortin MJ, Drapeau P, Legendre P (1989) Spatial autocorrelation and sampling design in plant ecology. Plant Ecol 83:209-222

> Franks PJS (1992) Sink or swim: accumulation of biomass at fronts. Mar Ecol Prog Ser 82:1-12

Genin A (2004) Bio-physical coupling in the formation of zooplankton and fish aggregations over abrupt topographies. J Mar Syst 50:3-20

> Greene CH, Pershing AJ (2004) Climate and the conservation biology of North Atlantic right whales: the right whale at the wrong time? Front Ecol Environ 2:29-34

Griffin RB (1999) Sperm whale distributions and community ecology associated with a warm-core ring off Georges Bank. Mar Mamm Sci 15:33-51

> Guisan A, Edwards TC, Hastie T (2002) Generalized linear and generalized additive models in studies of species distributions: setting the scene. Ecol Model 157:89-100

> Hamner WM, Hauri IR (1981) Effects of island mass: water flow and plankton pattern around a reef in the Great Barrier Reef Lagoon, Australia. Limnol Oceanogr 26: 1084-1102

> Haney JC (1986) Seabird segregation at Gulf Stream frontal eddies. Mar Ecol Prog Ser 28:279-285

Haney JC (1987) Aspects of the pelagic ecology and behavior of the black-capped petrel (Pterodrama hasitata). Wilson Bull 99:153-168

Harris RP, Wiebe PH, Lenz J, Skjoldal HR, Huntley M (2000) Zooplankton methodology manual. Academic Press, San Diego, CA

Hastie T, Tibshirani R (1990) Generalized additive models. Chapman \& Hall, New York, NY

Haury LR, McGowan JA, Weibe P (1978) Patterns and processes in the time-space scales of plankton distributions. In: Steele JH (ed) Spatial pattern in plankton communities. Plenum Press, New York, NY

Heywood KJ, Scrope-Howe S, Barter ED (1991) Estimation of zooplankton abundance from shipborne ADCP backscatter. Deep-Sea Res 38:677-691

Hirche HJ (1996) Diapause in the marine copepod, Calanus finmarchicus - a review. Ophelia 44:129-143

Hunt GL Jr, Russell RW, Coyle KO, Weingartner TJ (1998) Comparative foraging ecology of planktivorous auklets in relation to ocean physics and prey availability. Mar Ecol Prog Ser 167:241-259

Johnston DW, Read AJ (2007) Flow-field observations of a tidally driven island wake used by marine mammals in the Bay of Fundy, Canada. Fish Oceanogr 16:422-435 
Johnston DW, Thorne LH, Read AJ (2005) Fin whales Balaenoptera physalus and minke whales Balaenoptera acutorostrata exploit a tidally driven island wake ecosystem in the Bay of Fundy. Mar Ecol Prog Ser 305:287-295

Legendre P, Legendre L (1998) Numerical ecology. Elsevier, Amsterdam

Mercier F (1983) Feeding ecology and lipid deposition in migrating northern phalaropes in the Head Harbour region, New Brunswick. M.Sc. thesis, University of Guelph

Mercier F (1985) Fat reserves and migration of red-necked phalaropes (Phalaropus lobatus) in the Quoddy region, New Brunswick, Canada. Can J Zool 63:2810-2816

Mercier F, Gaskin DE (1985) Feeding ecology of migrating red-necked phalaropes (Phalaropus lobatus) in the Quoddy region, New Brunswick, Canada. Can J Zool 63: 1062-1067

Michaud J, Taggart C (2007) Lipid and gross energy content of North Atlantic right whale food, Calanus finmarchicus, in the Bay of Fundy. Endang Species Res 3:77-94

Morrison G, Gill RE, Harrington BA, Skagen S, Page GW, Gratto-Trevor CL, Haig SM (2001) Estimates of shorebird populations in North America. Occasional Paper No. 104. Canadian Wildlife Service, Ottawa

Murison LD, Gaskin DE (1989) The distribution of right whales and Zooplankton in the Bay of Fundy, Canada. Can J Zool 67:1411-1420

Pakhomov EA, McQuaid CD (1996) Distribution of surface zooplankton and seabirds across the Southern Ocean. Polar Biol 16:271-286

Pershing AJ, Greene CH, Jossi JW, O'Brien L, Brodziak JKT, Bailey BA (2005) Interdecadal variability in the Gulf of Maine zooplankton community, with potential impacts on fish recruitment. ICES J Mar Sci 62:1511-1523

Rodhouse PG, Prince PA, Trathan PN, Hatfield EMC and

Submitted: November 13, 2012; Accepted: April 22, 2013 others (1996) Cephalopods and mesoscale oceanography at the Antarctic Polar Front: satellite tracked predators locate pelagic trophic interactions. Mar Ecol Prog Ser 136:37-50

Townsend DW, Pettigrew NR (1996) The role of frontal currents in larval fish transport on Georges Bank. Deep-Sea Res II 43:1773-1792

Tremblay MJ, Sinclair MM (1992) Planktonic sea scallop larvae (Placopecten magellanicus) in the Georges Bank Region: broadscale distribution in relation to physical oceanography. Can J Fish Aquat Sci 49:1597-1615

van Franeker JA, van den Brink NW, Bathmann UV, Pollard RT, de Baar HJW, Wolff WJ (2002) Responses of seabirds, in particular prions (Pachyptila sp.), to small-scale processes in the Antarctic Polar Front. Deep-Sea Res II 49: 3931-3950

Vickery PD (1978) Northeastern maritime region. Am Birds 32:174-180

Werner FE, Page FH, Lynch DR, Loder JW and others (1993) Influences of mean advection and simple behavior on the distribution of cod and haddock early life stages on Georges Bank. Fish Oceanogr 2:43-64

> Wolanski E, Hamner WM (1988) Topographically controlled fronts in the ocean and their biological influence. Science 241:177-181

Wood SN, Augustin NH (2002) GAMs with integrated model selection using penalized regression splines and applications to environmental modelling. Ecol Model 157: 157-177

> Yee TW, Mitchell ND (1991) Generalized additive models in plant ecology. J Veg Sci 2:587-602

Zamon JE (2003) Mixed species aggregations feeding upon herring and sandlance schools in a nearshore archipelago depend on flooding tidal currents. Mar Ecol Prog Ser 261:243-255

Proofs received from author(s): July 9, 2013 